\title{
Akademik Ofislerin Verimlilik Üzerine Değerlendirilmesi: Mehmet Akif Ersoy Üniversitesi Örneği
}

\author{
Duygu KURTOĞLU' ${ }^{*}$, Mehmet Rafet KISTIR ${ }^{1}$ \\ ${ }^{1}$ Mehmet Akif Ersoy Üniversitesi, Mühendislik Mimarlık Fakültesi, Burdur \\ Geliş Tarihi (Received): 26.01.2018, Kabul Tarihi (Accepted): 06.03.2018 \\ $\square$ Sorumlu Yazar (Corresponding author*): duygukurtoglu@gmail.com \\ (C) +902482132788 且 +902482132704
}

ÖZ

Ofisler; yapılan organizasyonel faaliyetlere göre özelleşmiş, kullanıcıları tarafından gereksinim ve beklentiler doğrultusunda şekillenen, sonradan değiştirilmesi zor olan fiziksel durumları göz önüne alındığında kişilerin işteki performanslarını etkileyen çalışma mekanlarıdır. Birçok ofis yapısında olduğu gibi üniversitelerde de akademisyenlerin mesai saatlerinin bir kısmını geçirdikleri bu alanların kullanıcı üzerindeki etkisi, kişiden kişiye farklılık göstererek akademik verimliliğe katkı sağlamaktadır. Bu mekanların fiziksel koşullarının, kullanıcıların akademik performanslarına etkisini saptamak araştırmanın başlıca amacıdır. Derinlemesine inceleme yapabilmek için fiziksel koşullar ve psikolojik boyuttaki etkileşimleri değerlendiren konu alanı ile sınırlandırılmıştır. Sistematik olarak düzenlenen ofislerin yerine, kullanıcıların akademik performanslarını arttırmaya yönelik yaklaşımların ortaya konması amaçlanarak, mimarların tasarımları ortaya çıkan sonuçlara göre şekillendirmesine olanak tanınacaktır. Çalışmada Mehmet Akif Ersoy Üniversitesi İstiklal Yerleşkesinde bulunan Veteriner Fakültesindeki akademisyenlerin eş değer büyüklükteki çalışma mekanlarından duydukları memnuniyet değerlendirilmiş olup, anket ve görüşme ile veri toplanmıştır.

Anahtar Kelimeler: İşlev, konfor, ofis, performans, tasarım

\section{Evaluation of Academic Offices in Terms of Productivity: Mehmet Akif Ersoy University Sample}

\begin{abstract}
Offices are workspaces, where are tailored to organizational activities, are shaped by the users in the direction of needs and expectations, and affect the performance of the attendees when they are taken into account in their physical situations. As in many office buildings, the influence of these areas, where academicians spend part of their working hours in universities, contributes to the academic efficiency by varying person to person. It is the main purpose of investigating the physical conditions of these spaces to determine their effect on the academic performance of the users. It is limited to the subject area that evaluates the interactions in physical conditions and psychological dimension in order to conduct an in-depth study. Instead of systematically organized offices, architects will be able to shape designs according to the outcome, with the aim of revealing the approaches to increase the academic performance. In the study, the satisfaction of the academicians' equivalent dimensional offices at Mehmet Akif Ersoy University Faculty of Veterinary Medicine were evaluated and data were gathered through questionnaires and interviews.
\end{abstract}

Keywords: Function, comfort, office, performance, design 


\section{Giriş}

Ofisler, bünyesinde bir ya da daha fazla birey barındıran, kullanıcıların doğrudan ve pasif etkileşim içerisinde olduğu, farklı fiziksel boyut ve konumdaki çalışma birimleri olarak tanımlanabilir. Yapılan işin niteliği bu mekanların tasarımında önemli rol oynar. Hücre tipi ofis olarak da adlandırılan kapalı ofisler, etrafı duvarlarla sınırlandırılmış olup, mahremiyetin en fazla ve dış ortam ile etkileşimin en az olduğu ofis tipleridir. Diğer ofis tiplerine göre kullanıcının mekan üzerindeki kontrolü daha fazla olup, kişiselleştirilmesi kolaydır. Aidiyet duygusunun gelişebilmesi için çalışma alanlarının kişiselleştirilmesi, yönetimlerce tanınan özgürlükler ve sınırlandırmalar ile mümkün olmaktadır. Gereksinimler göz önüne alınarak psikolojik ve fizyolojik gerekli konfor koşullarının sağlanması ile iş veriminin artırılması amaçlanmaktadır (Altınok Kayan ve Tuncel, 2012).

Kapalı ofis birimleri arasındaki ilişki, bir ana arter etrafına dağılma ile sağlanmaktadır. Hiyerarşik düzene göre farklı konum ve boyutta kurgulanmış birimlerin farklı intiyaçlara cevap vermesi istenmesine karşın, her bireyin beklentileri bu mekanlar için farklıdır (Bailey,1990). İç mekan düzenlemeleri ile mekanın işlevi düzenlenebilse de, sonradan fiziki koşulların değiştirilebilmesi çok zor olmaktadır (Duffy, 1997; Soyak, 2009; Altınok Kayan ve Tuncel, 2012).

Daha önce yapılan çalışmalarda, birimlerin yapı içindeki konumlanmasına bağlı olarak kullanıcı memnuniyetinin değişkenlik gösterdiği ortaya konmuştur (İnce ve Dinç, 2008). Kullanıcı memnuniyeti mahremiyet, termal konfor, ses izolasyonu, mekanın aydınlatma ve havalandırma parametrelerine bağlı olarak değerlendirilmiş ve her bir parametrenin bireyler üzerinde fizyolojik ve psikolojik farklı etkileri olduğu gözlemlenmiştir (Vischer, 1989; 1996). Eş büyüklükteki ofislerde aynı işi yapan grup üzerinde yapılan araştırmada ise mekansal boyutun tek başına bir etken olmadığı, ölçülerin yanı sıra yönlenme ve kot farkının da önemli olduğu görülmüştür (İnce ve Dinç, 2008).

"Algı; nesnel dünyayı duyular yoluyla öznel bilince aktarma diğer ifadeyle bir şeye dikkati yönelterek, duyular yoluyla o şeyin bilincine varmadır" (Minez, 2013), bu da farkına varmayı bilinçli hale getirerek yaşam boyunca her edinimi yorumlamaya açar. Mimarın mekan ile kurduğu algısal ilişkideki beklenti, algılayan kişinin dikkatini yönlendirme eylemi ile bağlantılıdır ve kullanıcının mekana katıım sürecinden itibaren algısı isteyerek ya da istem dışı harekete geçmektedir. Algıya etki eden birçok faktör vardır. Mekansal bileşenlerin, kantiatif (yoğunluk, büyüklük, süre gibi) özellikleri sabit tutulsa bile, niteleyici (renk, düzey, koku gibi) özellikleri mekan algısında önemli bir etkendir (Kahvecioğlu, 1998; Yücedağ ve ark., 2018).

Bu çalışmadaki amaç, eş değer büyüklükteki ofislerden duyulan memnuniyetin belirleyici değişkenlerini tespit etmek ve akademik verimlilik üzerindeki etkisini araştırmaktır. Tasarım parametreleri değişkenlik göstermese de yaş ve akademik unvan mekan algısında önemli birer kriterdir.

\section{MATERYAL VE YÖNTEM}

\section{Çalışma Alanı}

Çalışma alanı olarak Mehmet Akif Ersoy Üniversitesi Veteriner Fakültesi Temel ve Klinik Bilimler binaları seçilmiştir. Temel Bilimler Binası her katta aynı plana sahip, farklı ana bilim dallarına ait ofislerin bulunduğu A, B, C, D bloğundan oluşan 3 katlı bir yapıdır. Ofislerin bulunduğu bölümler dersliklerden kapı ile ayrılarak, koridorun sağında ve solunda karşılıklı olacak şekilde konumlanmıştır. Duvarlar silikon esaslı su bazlı plastik boya ile boyanmıştır. Zemin laminant parke döşenmiştir. Tavanda ise $60 \times 60 \mathrm{~cm}$ taş yünü asma tavan vardır. Ayrıca her koridorda çay ocağı, WC ve toplantı odası bulunmaktadır (Şekil 1,2). Birimler hiyerarşik düzenin en alt kademesinden başlayacak şekilde tahsis edilmiştir. Koridorun sonundaki oda anabilim dalı başkanlarına aittir ve boyut olarak modülerliğin dışındadır. Bu mekanlar, farklılaşma nedeniyle araştırmaya dahil edilmemiştir.

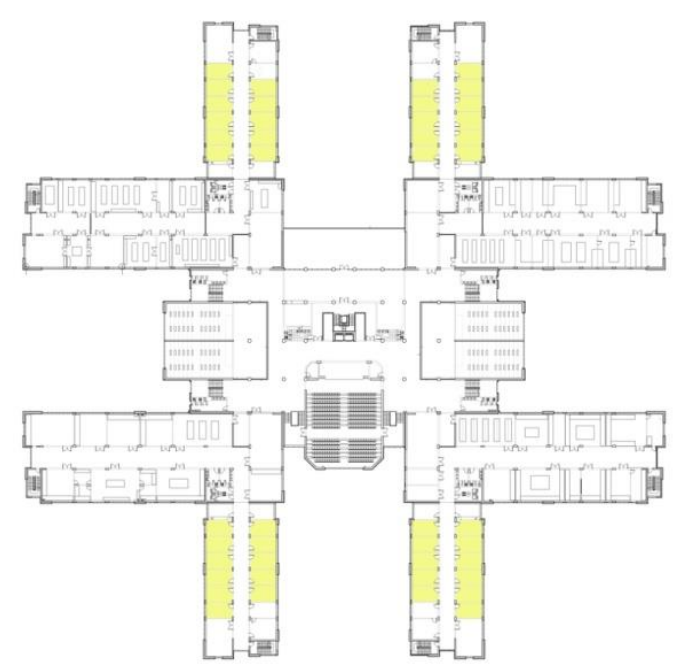

Şekil 1. Veteriner Fakültesi Kat Planı 


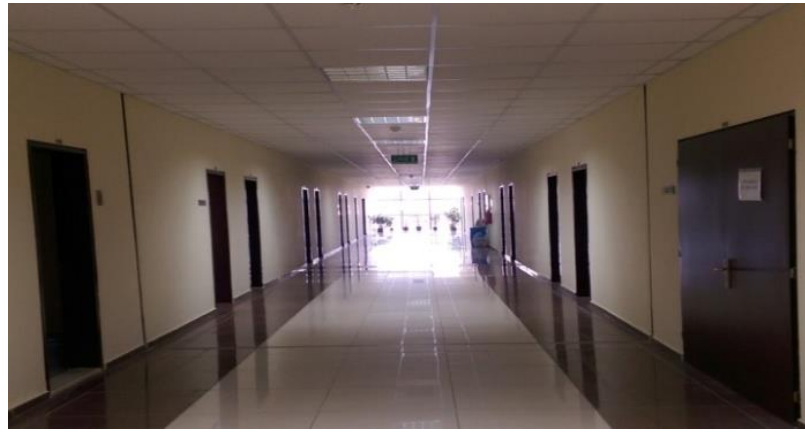

Şekil 2. Veteriner Fakültesi tipik ofis koridor örneği

\section{Yöntem}

Ekim 2016 - Aralık 2016 tarihleri arasında yapılan çaIışmadan elde edilen bulgular 20 soru ve onun alt sorularından oluşmaktadır. Bu sorulardan 22 tanesi teknik performansa, 5 tanesi işlevsel ve 5 tanesi algısal performansa aittir. Ankete her biri tek kişilik ofis birime sahip 50 akademisyen (7 Profesör, 14 Araştırma Görevlisi, 11 Yardımcı Doçent, 18 Doçent) katılmıştır. (Şekil 3) Teknik değer ölçüm sorularına 5 dereceli Likert ölçeği temel alınmış, algı ve aidiyet sorularının ise çift kutuplu ölçek ( $1=$ en pozitif, $5=$ en negatif) ile yanıtlanması istenmiştir. Anket sonucunda elde edilen değişkenlerin detaylı yorumlanabilmesi için IBM SPSS Statics programı kullanılarak tek yönlü ANOVA analizi yapılmıştır.

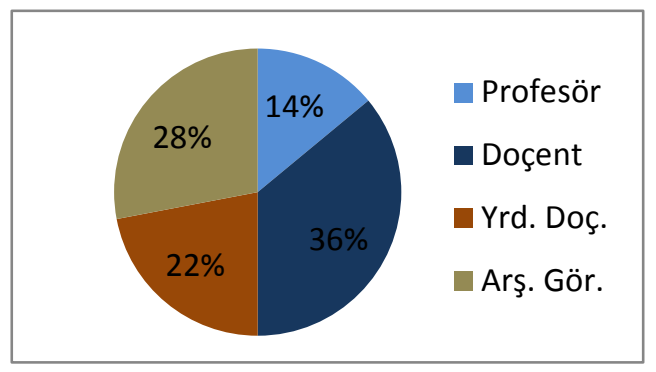

Şekil 3. Unvanlara göre katılımcı dağııım yüzdesi (Profesör: 7 kişi, Doçent: 18 kişi, Yardımcı Doçent: 11 kişi, Araştırma Görevlisi: 14 kişi)

\section{BULGULAR VE TARTIŞMA}

Anketten elde edilen verilerin güvenilirliği için ilgili bileşenler gruplanarak ortalama değerler oluşturulmuştur. Cevapların kendi içerisindeki tutarlıığı neticesinde araştırmanın ölçme isabetliliği "yüksek" olarak elde edilmiştir.

Mekanların kullanıcı ihtiyaçları neticesinde özelleştirilebilir olması, gerek duyulan teknik ve işlevsel perfor- mans bileşenlerinin her biri için değiştirilebilirliği belirtmektedir. Araştırma sırasında saptanan termal konforun sağlanamadığı zamanlarda mevcut sisteme ek olarak ısıtıcı ve vantilatör kullanmak, ofis mobilyalarının yetersiz ya da estetik zevklere hitap etmemesi durumunda bireysel olarak almak gibi uygulamalar görülmüştür. Buna rağmen teknik etmenlerin en memnuniyetsiz durum olması, birimlerdeki özelleşmenin olumlu bir yansıma bulmasını garantilemediği belirlenmiştir.

Elde edilen verilerin analizinde 0 en pozitif ve 3 en negatif değer olarak alındığında, en az hoşnut olunan durum $3^{\prime}$ e en yakın değerdir. Memnuniyet sonuçlarına bakıldığında en negatif değerlendirilen etmen çalışma ortamlarının teknik performansıdır. Bu performans özelinde ise termal konfor en negatif bileşen olarak ifade edilmiştir (Şekil 4). Üç ana başlık altında incelenen etmenlerin verimlilik üzerine etki değerleri, değişkenleri arasındaki olumsuzdan olumluya doğru olan sıralama şu şekildedir:

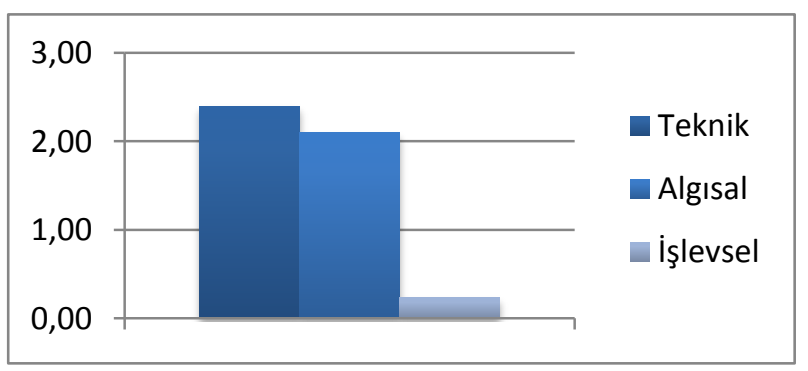

Şekil 4. Teknik, Algısal ve işlevsel değişkenlerine ait ortalama değerler (Teknik performans < Algısal etmenler $<$ İşlevsel performans)

\section{Farklılaşma Değişkenleri}

Yapı tasarımı simetriktir. Birbirinin benzeri olan sekiz blok, sirkülasyon araçlarının bulunduğu merkez kütle ile bağlantılıdır. Yalnızca giriş cephesi zemin katta farklılaşma göstermektedir. Bu cephede yaya yoğunluğu daha fazladır (Şekil 5). İncelenen mekanların eş büyüklük ve yapısal benzerliğinin olmasının yanı sıra memnuniyet değerlendirmesinde yapının bulunduğu kat ve cephedeki farklılıkları saptamadan elde edilen sonuçların güvenilirliği olmamaktadır. Bu nedenle farkların belirlenerek aynı birimin tekrarlanmasıyla oluşturulan ofis düzeninin bu değişkenler üzerinden değerlendirilmesi gerekmektedir. Yapılan çalışmada aynı cephe ve kat içerisinde bulunan birimler ayrı ayrı ele alınmış, farklılıklardan etkilenen ve etkilenmeyen değişkenlerin neler olduğu belirlenmiştir. 


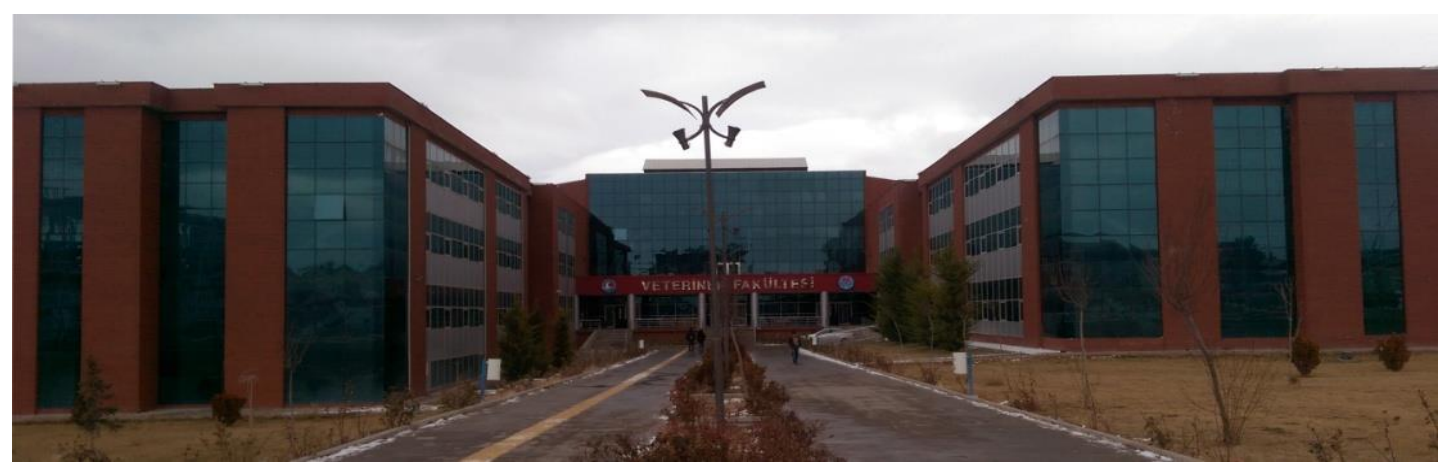

Şekil 5. Veteriner Fakültesi Temel Bilimler Binası giriş cephesi

Veriler neticesinde cephedeki farklılıkların yalnızca algısal performans üzerinde etkili olduğu sonucuna ulaşılmaktadır (Tablo1). Söz konusu farklılık Antalya karayolu ile İdari ve İktisadi Bilimler Fakültesine (IIIBF) bakan cepheler arasında olduğu belirlenmiştir. Özellikle yük taşımacılığı araçlarının sık kullandığı karayoluna bakan cephede gürültü ve manzara gibi faktörlerden dolayı aidiyet kavramı az iken IİBF cephesinde hareketlilik pozitif etki olarak karşımıza çıkmaktadır.

Birbirinin simetriği olan iki cephede farklı manzara özelliklerine ve termal koşullara sahip 11 birim bulunmaktadır. Çalışmada faydalanılan gün ışığı miktarı ölçülemediği için, bu etmen algısal faktörler dahilinde incelenmiştir.
Anketten elde edilen verilere göre giriş yönüne bakan cephelerin kullanıcılar üzerinde daha çok pozitif etki yarattığı, mekanı benimseme ve çalışma isteğini arttırdığı belirlenmiştir. Diğer cephelerin baktığı manzara yönündeki arazinin boş olması ve yeterli peyzaj düzenlenmesinin yapılmamasından dolayı kişilerde yalnızlık duygusunu tetiklediği belirtilmiştir.

Öğrenci hareketliliği, camların ayna olarak kullanması, ışık açık olunca mekan içinin görünmesi gibi nedenlerle bu katları negatif olarak değerlendirmişlerdir. Diğer değişkenler için ise bir yorum yapılmamıştır. Binanın çevresinin açık olması, güneşten faydalanmak için pozitif etki sağlamaktadır.

Tablo 1. Performans önem dağılımı

\begin{tabular}{|l|c|c|c|c|c|c|c|c|c|}
\hline & \multicolumn{4}{|c|}{ Teknik Performans } & \multicolumn{3}{c|}{ İşlevsel Performans } & \multicolumn{2}{c|}{ Algısal Performans } \\
\hline Unvan & $\begin{array}{c}\text { Boyut ve } \\
\text { yönlenme }\end{array}$ & $\begin{array}{c}\text { Termal } \\
\text { konfor }\end{array}$ & Gürülü & $\begin{array}{c}\text { Aydınlan- } \\
\text { ma }\end{array}$ & WC & Mobilya & Özürlü & Aidiyet & Güvenlik \\
\hline Profesör & $\% 14$ & $\% 30$ & $\% 100$ & $\% 14$ & $\% 0$ & $\% 100$ & $\% 58$ & $\% 30$ & $\% 90$ \\
\hline Doçent & $\% 60$ & $\% 50$ & $\% 50$ & $\% 50$ & $\% 6$ & $\% 55$ & $\% 82$ & $\% 55$ & $\% 50$ \\
\hline $\begin{array}{l}\text { Yrd. } \\
\text { Doçent }\end{array}$ & $\% 90$ & $\% 100$ & $\% 45$ & $\% 36$ & $\% 27$ & $\% 45$ & $\% 100$ & $\% 72$ & $\% 50$ \\
\hline Arş. Gör. & $\% 100$ & $\% 50$ & $\% 14$ & $\% 7$ & $\% 35$ & $\% 22$ & $\% 70$ & $\% 84$ & $\% 57$ \\
\hline
\end{tabular}

\section{Yapısal Etkenler}

20. yy ofis tasarımlarında tek tip ve sıradan olan, değişen koşullar karşısında esnek olmayan, herhangi bir şekillendirmeye olanak tanımayan yaklaşımlar revaçta iken, 21. yy da çalışma ortamının mekansal boyutları, yönlenmesi, hava kalitesi, aydınlanma düzeyi ve gürültü gibi faktörlerin insan sağlığı, davranışı ve üretkenliği üzerindeki etkileri (Gonzalez ve ark., 1997) ve organizasyonun örgütsel yapısına ve is koluna uygun farklı çözümlemelerin gerektiği anlaşılarak teknoloji ve esneklik beraber kullanılmaya başlanmıştır (Duffy, 1992;
1997; Myerson ve Ross, 2003; Çimen, 2008; Soyak, 2009).

\section{Mekanın Boyutları}

Ofisler, değişen kullanıcı davranışları karşısında günün belirli saatlerinin geçirildiği mekanlar olmaktan çıkarak, algısal olarak da özelleşmiş mekanlardır. Algı, bir şeye dikkati yönelterek o şeyin bilincine varma, idrak etme olarak tanımlanmaktadır (TDK, 2016). Algısal süreçte, dış dünyadaki olaylar, nesneler ve kişiler iç dünyamızda yorumlanarak bir bütün haline getirilir. Mekanın farklı bireylerce algılanması ve tanımlanması değişkenlik 
gösterir. Bu nedenle yapısal etkenlerde algıyı göz önünde bulundurmak gerekmektedir.

Görsel algıda Kurt Koffka, Max Wertheimer ve Wolfgang Köhler'in öncüsü olduğu, Bauhaus okulu tarafından da kabul gören Gestalt Teorisi, tasarımcıların sıklıkla başvurduğu bir kuram olup, zihnin parçalı olarak algıladığı şeylerden bütüne nasıl ulaştığını ortaya koyan, algılama sürecinde etkin rol oynayan elemanları, algı ve algısal örgütlenme bağlamında ele alan düşünce şeklidir. Wertheimer, Gestalt Kanunlarında algıyı araştırarak benzerlik, yakınlık, süreklilik ve kapalılığın gerekliliğini ortaya koymuştur (Güngör, 2005).

Mekanın ve donatıların renk, doku ve malzeme kalitesi, mahremiyet, güvenlik, sosyalliğe katkısı, estetik ve aidiyet kavramları kişinin mekan algısında kilit rol oynar.

Gestalt teorisine göre nesnenin algısı farklı durumlara göre değişkenlik gösterir (Koffka, 1935):

Yakınlık Kanunu (Proximity) : Birbiri arasındaki mesafenin az olduğu durumlarda nesnelerin bir bütünmüş gibi (grup olarak) algılanmasıdır.

Benzerlik Kanunu (Similarity): Şekil ve/ veya işlev açısından benzer özellik gösteren elemanların bütün olarak değerlendirilmesidir.

Kapalılık Kanunu (Closure): Boşlukları doldurarak nesneyi bir bütün gibi algılama olarak açıklanabilir.

Simetri Kanunu (Symetry): Simetrik şekillerin daha kolay ve bütüncül algılanmasıdır.

Mekan boyutlarının belirlenmesinde kullanıcı sayısı, yapılan işin ve gerekli donatıların ölçüleri tasarımda belirleyici faktördür. Fakat fiziksel ölçülerinin yanı sıra duyusal boyutu, kullanılan donatıların büyüklüğü, rengi, dokusu vb. gibi tasarım özelliklerine göre değişkenlik gösterir. Aynı ölçülere sahip, kişiselleştirilen iki ofis birbirinde farklı boyutlarda algılanır.

Araştırmaya katılan tüm ofislerin ölçüsü $4 \times 5.1 \mathrm{~m}$ dir. Mekan boyutlarının önemi yaşa ve unvana göre değişkenlik göstermektedir. Araştırma görevlileri tarafından ofislerin büyük olması istenen bir durum iken, profesörler için önem teşkil etmemektedir. Bu duruma sebep olarak öğretim yardımcılarının odalarında daha fazla misafir ağırladıkları, öğrencilerle ders dışı zamanlarda görüşme için kullandıkları gösterilmiştir. Katılımcıların \%86'sı üniversitenin temin ettiği donatıları kullanırken, diğerlerini kendi istek ve intiyaçları doğrultusunda dekore ettiği, mekanın boyutsal algısı üzerindeki etkisi olduğu gözlemlenmiştir.

\section{Termal Konfor}

Ekonomik olma, ekolojik dengenin sürdürülebilmesi ve insan sağlığını tehdit eden etmenlerin ortadan kaldırılması doğal kaynaklardan yararlanmak için başlıca nedenlerdir. Ülkemizde güneşli gün sayısının fazla olması, tasarımda mutlaka göz önünde bulundurulması gereken bir gerçektir. Farklı yönlere bakan mekanların doğrudan güneşten faydalandıkları gün sayısı ve saatleri, arazinin eğimi, profil açısı ve yapının şekline göre değişkenlik gösterir (Ak, 1993). Cephelerin faydalandıkları güneş ışığı miktarı, aydınlanma ve termal konfora etki etmektedir.

Termal konfor (TS EN ISO 9004, 2001);

- İdeal sıcaklık

- İdeal nem oranı

- Yeterli havalandırma olarak tanımlanır.

İç hava kalitesinin kullanıcıların fizyolojik ve psikolojik sağlığı üzerindeki etkisi iş verimliliği açısından önemli bir parametredir. Kapalı mekanlarda ideal sıcaklığının $18-21{ }^{\circ} \mathrm{C}$ (WHO, 2007-+) ve nemin \%30-60 arasında olması gerekmektedir (ASHRAE, 2001). Ideal hava akımı ortalama $150 \mathrm{~mm} / \mathrm{sn}$ olmalıdır ve bu değer 100 $\mathrm{mm} / \mathrm{sn}$ düzeyinin altında ise ortam "havasız" nitelendirilir. Yeterli olarak havalandırılan ortamlardaki hava kalitesinin artmasına bağlı olarak baş ağrısı ve rahat düşünebilmedeki zorluk gibi Hasta Bina Sendromu (SBS) azalarak iş verimliliği ve üretkenlik artmaktadır (Fanger, 2002) .

Çalışmaya katılan ofislerde kaloriferin yandığı ve yanmadığı durumlardaki ısı farklarını belirlemek için, Ekim ve Aralık aylarında öğle saatinde olmak üzere 2 defa sıcaklık ölçümü yapılmıştır. Ekimde iç ortam sıcaklığı ortama $19{ }^{\circ} \mathrm{C}$ olarak kaydedilirken, Aralık ayında $26{ }^{\circ} \mathrm{C}$ dir. Bu sıcaklık, farklı katlarda önemli bir değişkenlik göstermemektedir. Buna karşın, pencere ve kapı kapalı durumda, Güneydoğu ile Kuzeybatıya bakan cepheler arasındaki ısı farkı $3^{\circ} \mathrm{C}$ ölçülmüştür. Aralık ayında ise kaydedilen değer ideal şartların üstüne çıkmıştır. Katılımcıların tamamı ısı kaynağını kontrol edemediklerinden dolayı pencerelerin sürekli açık olduğunu, binanın konumundan dolayı çok rüzgar aldığını ve bu nedenle açık pencerenin sorun oluşturduğunu belirtmişlerdir. Nem oranı ve havalandırma faktörleri araştırma dışında bırakılmıştır.

Anket sonuçlarına göre termal konfor en çok yardımcı doçentler tarafından önemsenmektedir. Profesörler IS। kontrolünü klima ve ısıtıcı ile yapabildiklerini belirtmişlerdir. Konfor koşullarının doğal yollarla sağlanmasını diğerler unvan gruplarına göre daha az dikkate almaktadırlar. 


\section{Aydınlanma}

İç mekan aydınlatması çeşitli faktörlere bağlı olarak değişkenlik gösterir (Tablo 2). Doğal ve yapay aydınlatmaya etki eden faktörler şu şekildedir:

Tablo 2. Aydınlatma etki faktörleri

\begin{tabular}{|l|l|}
\hline Doğal Aydınlatma & Yapay Aydınlatma \\
\hline Pencere açıklıkları & Lambanın özellikleri \\
\hline Güneş kontrolü & Cihaz özellikleri \\
\hline Cam çeşidi & Temizlik \\
\hline Bina dışı engeller & Kontrol sistemi \\
\hline Yörenin koordinatları & $\begin{array}{l}\text { Yüzey- aydınlatıcı arasın- } \\
\text { daki mesafe }\end{array}$ \\
\hline
\end{tabular}

Aydınlatma Şiddeti: Bir yüzeye düşen ışık miktarına aydınlatma denir ve birimi lükstür. 1 lüks= 1 lümen $/ \mathrm{m}^{2}$ dir. Lümen, lümenans akı birimidir. Birimi Kandela olan lümenans, bir yüzey tarafından yansıyan ya da emilen ışık miktarına verilen addır (prEN 15193, 2006).

Aydınlatma şiddeti güneşli havada açık mekanlarda gündüzleri 2.000-100.000 arasında geceleri ise 50-500 lüks arasında değişmektedir. Ofis çalışmaları için gereken aydınlatma şiddeti TS EN 12464-1 (2013) standardına göre 500 lüks olarak belirlenmiştir.

Yetersiz aydınlatma sonucunda oluşan göz yorgunluğu ve depresyon, fazla aydınlatma ile göz kamaşması ve dikkat dağınıklığı meydana gelebilmektedir. İç mekanların aydınlatmasında kullanılan doğal ve yapay kaynaklar, konfor koşulları sağlanırken aynı zamanda estetik açıdan da desteklenmelidir.

Hacimdeki farklı pencere sayısına ve yerleşim düzenine göre toplam aydınlanmayı bulabilmek için aşağıdaki parametreleri bina tasarımına dahil etmek gerekmektedir. Mekanlardaki aydınlanmayı hesaplamak için PrEN 15193 (2006) standardında yer alan bağıntılar aşağıdaki şekildedir:

AC: Pencere alanı $\left(\mathrm{m}^{2}\right)$

$\mathrm{AC}=\mathrm{hpen} \mathrm{x}$ wpen

hpen: Pencere yüksekliği $(m)$

wpen: Pencere genişliği (m)

AD: Gün ışığından yararlanan yatay çalışma düzleminin alanı $\left(\mathrm{m}^{2}\right)$

$A D=a d x$ bd

bd: Günışığından yararlanan bölgenin uzunluğu

(m)

ad: Günışığından yararlanan bölgenin derinliği (m)

$\mathrm{a} \mathrm{d}=2.5 \times$ (hli- hçd) $\mathrm{bd}=$ wpen $+\mathrm{ad} / 2$

hli: Lentonun yerden yüksekliği $(m)$

hçd: Çalışma düzlemi yüksekliği $(\mathrm{m})$

Çalışmaya konu olan Mehmet Akif Ersoy Üniversitesi Veteriner Fakültesi'nin standart ofis boyutu $20.55 \mathrm{~m}^{2}$ dir. Yapılan analiz ve hesaplamalar dahilinde, açık havada, bu odanın maksimum $17 \mathrm{~m}^{2}$ si doğal ışıktan yararlanmaktadır. Fakat hesaplamalar donatıların yerinin doğru konumlandığı, yani kişi çalışırken gölgesinin çalışma düzlemine düşmediği varsayılmıştır.

Doçentlerin yarısı doğal aydınlanmanın önemli olduğunu ve verimliliği direkt etkilediğini belirtmişlerdir. Şaşırtıcı olarak, binanın çevresinde ışık kesici bir engel olmaması ve havalanın açıklığına rağmen anket uygularken tüm ofislerde ışıkların açık olduğu gözlemlenmiştir.

\section{Gürültü}

Gürülttü , "aralarında uyum bulunmayan düzensiz seslerin bütünü" (TDK, 2016) olarak tanımlanır ve istenmeyen bir durum olarak karşımıza çıkar. İnsan kulağı 0$140 \mathrm{~dB}$ aralığındaki ses şiddetine karşı duyarlıdır(Tablo 3). Kamu Kurum ve Kuruluşlarında gürültü seviyeleri kapalı pencere Leq si ort. 45, açık pencere Leq ise 55 $\mathrm{dB}$ dir ve bu değerler insan sağlığına fiziksel olarak zarar verecek düzeyde değildir (Ulucan ve Zeyrek, 2012).

Tablo 3. Gürültünün Fizyolojik Etkileri (Ulucan ve Zeyrek, 2012)

\begin{tabular}{|cl|}
\hline Gürültü Düzeyi & Yer ve Konum \\
\hline $0 \mathrm{~dB}$ & Işitme eşiği \\
\hline $20 \mathrm{~dB}$ & Sessiz bir ortam \\
\hline $30 \mathrm{~dB}$ & Fısıltı ile konuşma \\
\hline $40 \mathrm{~dB}$ & Sessiz bir oda \\
\hline $50-55 \mathrm{~dB}$ & Şehirde bir büro \\
\hline $60 \mathrm{~dB}$ & Karşlıklı konuşma \\
\hline $80 \mathrm{~dB}$ & Yüksek sesle konuşma \\
\hline $90 \mathrm{~dB}$ & Kuvvetlice bağırma \\
\hline
\end{tabular}

Mekanın özelliklerine (boyut, yalıtım, konumu vb.) göre değişkenlik göstermekle birlikte dikkat dağınıklığı, algıda azalma, asabiyet, insan ilişkilerinde problemler, yorgunluk ve bunlara bağlı olarak iş veriminin düşmesi gürültünün psikolojik etkileri arasındadır (Sundstrom ve ark., 1994). 
Ankete verilen cevaplarda ofislerdeki gürültünün genellikle öğrenci odaklı olduğu, kimi zaman ise diğer odalardan gelen telefon görüşmesi, sohbet gibi yüksek sesle konuşmalardan kaynaklandığı belirtilmiştir. Bu nedenle gürültü düzeyini ölçmek için, her birimde ve katta, ders saati ve ders saati dışında olmak üzere Sonometre ile 2 kez ölçüm yapılmıştır. Ölçme sırasında koridor kapıları açık bırakılmıştır. Düşeyde aynı hizada bulunan mekanlar için ortalama değerler alınmıştır. Çıkan sonuçlara göre, sınıflara en yakın odalardaki gürültü düzeyi ders arasında $67 \mathrm{~dB}$, ders saatleri içerisinde $45 \mathrm{~dB}$, koridorun sonundaki odada ise ders arasında $49 \mathrm{~dB}$, ders saatinde ise $29 \mathrm{~dB}$ dir. Diğer ofislerdeki düzey ise bu sonuçların arasında değişmektedir. Dersliklerden uzaklaştıkça gürültü azalmaktadır. Profesörlerin ofisleri koridorun en sonunda konumlanmaktadır. Yapılan çalışmada en sessiz bu mekanlar çıkmasına rağmen, gürültüden en çok bu unvan grubu rahatsız olmaktadır (Şekil 6).

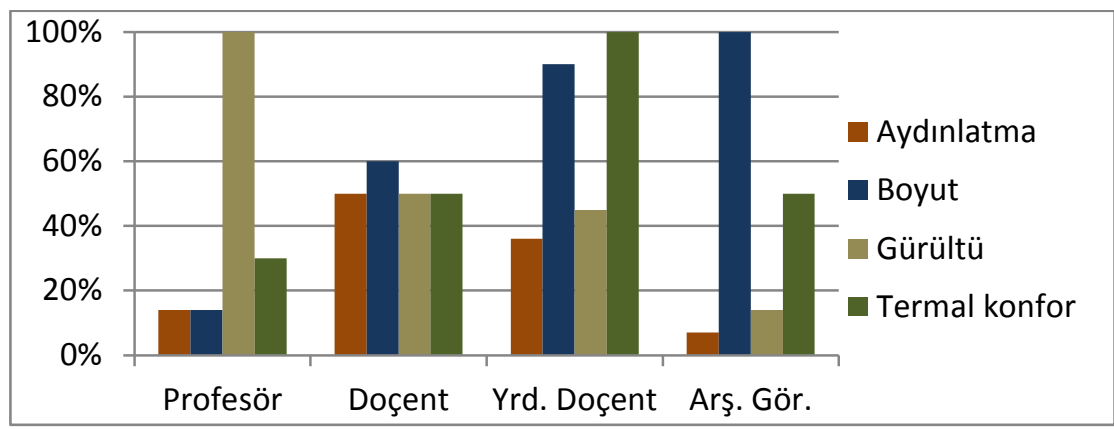

Şekil 6. Yapısal Memnuniyetin Unvanlara Göre Dağılımı

\section{İşlevsel Etkenler}

Ofis birimlerinin yapı içerisindeki konumu (WC'lere, çay ocağına yakınlığı vb.), mobilyaların yeterli, kullanışlı ve işe uygun olması, özürlülere göre tasarımın göz önünde bulundurulması gibi işleve yönelik etkenlerdir (Şekil 7).

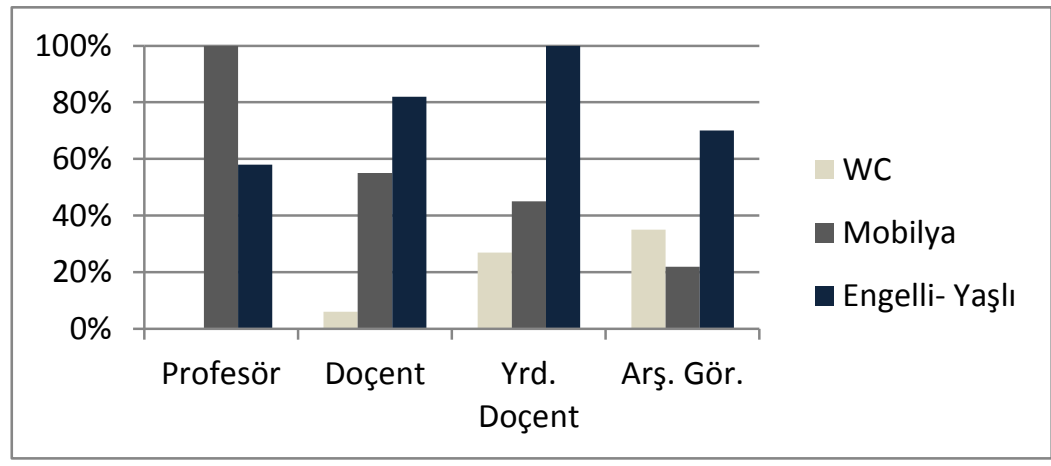

Şekil 7. İşlev-Memnuniyet Grafiği

\section{Tuvaletler ve Lavabolar}

Ortak kullanılan tuvaletler sorunların başında gelmektedir. Ortak kullanım mekanlarında temizliğe dikkat edilmemesi, yeterli havalandırılmanın sağlanmaması durumunda rahatsız edici kokunun oluşmasına neden olmaktadır. Ayrıca bu mekanlarda gerekli aydınlatmanın sağlanması, çalışılan yer ile aynı katta olması ve direkt olarak ofis koridoruna açılmaması gerekmektedir.

Ofisin ortak kullanım alanlarıyla etkileşimi üzerine yapılan değerlendirmede profesörler koku ve mahremiyet nedeninden dolayı, WC lerden uzak konumlanmayı istemektedirler (Şekil 7). Tuvalet kapıları sürekli kilitli tutulmaktadır. Belirtilen bir başka neden bu mekanların ses yalıtımlarındaki yetersizliktir.

\section{Mobilya Seçimi}

Ergonomiye uygun olmayan mobilya seçimi başta kasiskelet sistemi ve dolaşım sistemi hastalıkları olmak üzere, alerjik hastalıklar, göz ve duyma bozukluklarına, ayrıca psikolojik rahatsızlıklara sebep olmaktadır (Karaer, 2016). 
Araştırma sırasında odaların intiyaç ve zevk doğrultusunda özelleştirildiği görülmüştür (Şekil 8). En belirgin özellik ise bazı odalarda bulunan kanepelerdir. Katılımcılar özellikle çalışma sandalyelerinin ergonomiye uygun olmadığını, bu nedenle uzun süre oturdukları zaman sırt ağrısı çektiklerini belirtmişlerdir. Bir kısmı bel yastığı kullandığını, fakat yeterli gelmediği de eklemiştir. Bir başka olumsuz görüş ise kitaplıklardır. Mevcut kitaplıklar yetersiz gelmektedir. Odalara eklenen farklı sandalyeler de göstermektedir ki standart olarak verilen misafir koltuğu sayısı intiyacı karşılamamaktadır.

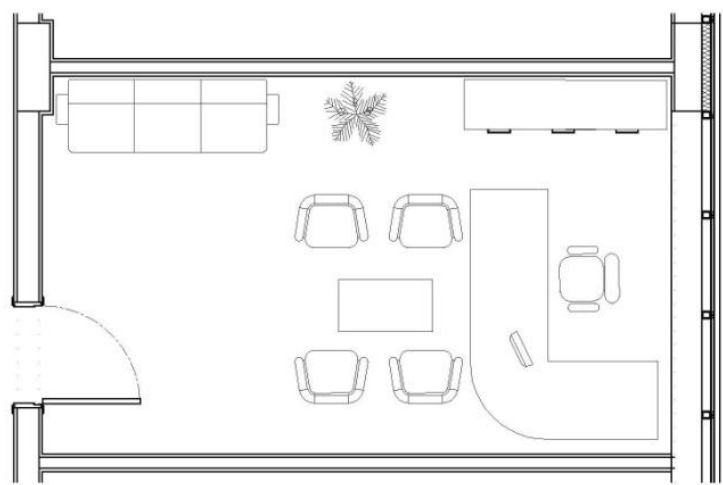

Şekil 8. MAKÜ Veteriner Fakültesi standart öğretim elemanı ofisi (solda), özelleşmiş öğretim (sağda)

\section{Engelliler için Ofis Mekanları}

Birleşmiş milletler Genel Kurulu'na göre ; " Normal kişilerden farklı olarak sosyal yaşantısında kendi kendine yapması gereken işleri bedensel ve zihinsel kabiliyetindeki kalıtımsal ya da sonradan olma bir engelden dolayı yapamayanlara bedensel ve ya zihinsel özürlü denir" (UN, 1975; Gündüz, 1996).

Krumlin'e Göre Özür Gruplarına Göre Sınıflandırma (Mutluer,1997) ;

\begin{tabular}{|c|l|}
\hline A. Duyusal Özüllüler & B. Bedensel Özürlüler \\
\hline $\begin{array}{c}\text { 1.Görme özürlüler } \\
\text { Şaşılı̈, Göz kusurları, } \\
\text { Körlük }\end{array}$ & $\begin{array}{l}\text { 1.Kas ve iskelet özürlüleri } \\
\text { Bedensel kusurlar, kalça } \\
\text { mafsalı çıkıkları, bel ke- } \\
\text { miği hasarları, mafsal ilti- } \\
\text { hapları, mafsal kireçlen- } \\
\text { meleri, kas zayıflamaları }\end{array}$ \\
\hline $\begin{array}{l}\text { 2.lşsitme özürlüler } \\
\text { Işitme güçlüğü, sağırlık }\end{array}$ & 2. Beyin- omurilik özürlüleri \\
\hline $\begin{array}{l}\text { 3.Konuşma özürlüler } \\
\text { Kekemelik, dilsizlik, la- } \\
\text { renks (gırtlak) kayıpları }\end{array}$ & 3. İç organ özürlüler \\
\hline & $\begin{array}{l}\text { 4. Belirli bir maddeye karşı } \\
\text { duyarlılık }\end{array}$ \\
\hline
\end{tabular}

Mutluer (1997)'in sınıflandırmasına göre ise bedensel engelliler;
A. Yürüyebilen Özürlüler

a. Hiçbir yardıma gerek olmadan yürüyebilenler

b. Tutamak ya da bastonla yürüyebilenler

c. Koltuk değneği ya da komplike bir aparatla yürüyebilenler

\section{B. Tekerlekli Sandalyeye Bağlı Özürlüler}

a. Tekerlekli sandalyeye bağlı olup kısmen yürüyebilenler

b. Vücudunun üst kısmını tamamen kullanabilenler

c. Vücudunun üst kısmını da kullanamayan ağır özürlülerdir.

Engelli kişilerin sağlıklı bireylerle şartlarının eşitlenmesi için problem yaşamadan tüm binayı kullanabilmeleri gerekmektedir. Bedensel engellilere yapılan tasarımlarda özür derecesini ve ergonomik ölçüleri bilmek, kişinin yaşadığı fiziksel ve psikolojik zorlukları yenerek üretebilmesine olanak sağlamaktadır. $\mathrm{Bu}$ araştırma kapsamında hareket olanağı kısıtlı engelli bireyler ele alınmıştır.

Yapılan araştırmada katılımcıların tamamı binada özürlülerin de rahatça çalışabileceği en az bir tane özelleşmiş ofisin ve tuvaletin bulunması gerektiğini belirtmiş fakat bina tasarımında bu kişilerin göz ardı edildiği görülmüştür. 


\section{SONUÇLAR VE ÖNERILER}

Çalışma alanı olarak seçilen yapı akademisyenlerin ve öğrencilerin ortak kullanım alanı olup, ofisler dersliklerden ayrılmıştır. Lineer düzende, eş büyüklük ve parametrelere göre tasarlanan ofis bloklarının, aynı işi yapan kullanıcıların memnuniyeti ve verimliliği üzerindeki etkisi araştırılmıştır.

- Farklı katlarda lineer düzende konumlanan eş büyüklükteki ofisler, her kullanıcı için aynı memnuniyet derecesini sağlamamakta, huzurlu olarak çalışılamayan ortamda verimliliğin düştüğü gözlenmektedir. Ankete verilen cevaplarda, ders saat dışında öğrenci kabul eden akademisyenler daha büyük mekanlara intiyaç duyarken, ofisini yalnızca kişisel çalışmaları için kullananlar için mekânsal büyüklük önemli değildir.

- Termal konfor yardımcı doçentler için birincil memnuniyet faktörüdür. Buradan elde edilen sonuç, oda ısısının ve hava kalitesinin yetersiz olduğu durumlarda dış faktörler (klima, ısıtıcı, buhar makinesi vb.) yardımıyla kontrol edilmekte olduğudur.

- Diğer etken olan gürültü toleransı profesörlerde en düşüktür. Dikkat dağıtıcılardan daha fazla ve kolay etkilendiklerini belirtmişlerdir. Unvan derecesi azaldıkça tolerans artmaktadır. Ayrıca yapı dışından gelen gürültü gibi dikkat dağıtıcıların zemin katlarda verimliliği düşürdüğü görülmektedir.

- Yeterli aydınlatma doçentler için tercih sebebidir. Anket çalışması sırasında gündüz bile ışıkların açık olduğu gözlemlenmiştir. Diğer bir nokta ise mobilyaları konumlandıırken gölge düşme yönü önemsenmemiştir. Bu durum mekanın olduğundan daha karanlık algılanmasına sebep olmaktadır.Okuma yaparken doğal ışığa en yakın olduğu için beyaz ışık tercih sebebidir.

- İç mekan donatılarının ergonomisi, işlevselliği ve estetikliği ise deneyim artıkça önem kazanmaktadır. Zevklerin gelişip, deneyimle birleşmesinden kullanışlı ve şık mekanlar ortaya çıkmıştır.

- Mekanın konumlanması, ışık ve havalandırma düzeyi, boyutları gibi etkenler sabit tutulsa da insan faktörü değişkendir. Dolayısıyla, ofislerden duyulan memnuniyetin yaşa ve unvana göre değiştiği görüşü bu çalışma ile desteklenmiştir.

Yapılan çalışma göstermektedir ki, akademik ortamda unvana bağlı olarak memnuniyet derecesi değişmekte, tek tip ofisler farklı kullanıcıların istek ve intiyaçlarını karşılayamamakta ve işteki performansına etki etmektedir. Bu nedenle çeşitlilik önem arz etmektedir.

Elde edilen verilere göre ofis katları ile öğrencilerin kullanım alanlarının farklı katlarda olması mahremiyet ve güvenlik açısından önerilmektedir. Odalar tek tip olmak yerine intiyaçlara cevap verebilecek şekilde işlevsel, esnek ve doğal ışık maksimum seviyede kullanılmasına olanak sağlayan, farklı büyüklerde dizayn edilmelidir. Bu tasarımlar yapılırken engelli ve yaşılar da göz önünde bulundurulmalıdır. Kuzey cephelerin hem aydınlanma hem de termal konforu düşürdüğü bilindiğinden mümkün olduğunca çay ocağı, toplantı salonu gibi ortak kullanım alanları buralarda konumlandırılmalıdır. Tuvaletlerin havalandırmasına dikkat edilerek, aynı koridorda fakat mümkün olduğunca odalardan uzakta çözülmelidir.

\section{KAYNAKLAR}

Ak, F. (1993). Enerji Etkin Konut ve Yerleşme Birimi Dizaynında Uygulanabilecek Bir Yaklaşım. İstanbul Teknik Üniversitesi Fen Bilimleri Enstitüsü, Yüksek Lisans Tezi, İstanbul.

Altınok Kayan, H.Z., Tuncel, D. (2012). Ofis İç Mekan Tasarımlarında Gelişen Teknolojiler Işığında Esneklik. Tasarım+Kuram Dergisi 8 (14): 79-95.

ASHRAE (2001). Standard 62- 2001- Ventilation for Acceptable Indoor Air Quality, American Society of Heating, Refrigerating and Air-Conditioning Engineers. Atlanta.

Bailey,S. (1990). Offices: A Briefing and Design Guide. Butterworth Scientific, UK.

Çimen, T. (2008). Teknolojik Gelişmelerin Sonucunda Değişen Üretim İlişkilerinin Ofis Yapılarına Etkisi ve Ofis Ekipmanları. İTÜ Fen Bilimleri Enstitüsü, Yüksek Lisans Tezi, İstanbul.

Duffy, F. (1992). The Changing Workplace. Phaidon, London.

Duffy,F. (1997). The New Office. Conran Octopus, London.

Fanger, O. (2002). Çev.: Bekir Ünlüoğlu. İç Hava Kalitesinin İyileştirilmesi ve Ofis Verimliliğinin

Artırılması. Türk Tesisat Mühendisleri Derneği Dergisi 54 (19).

Gonzalez, M.S.R., Fernandez, C.A., Cameselle, J.M.S. (1997). Emprical Validation of A Model of User Satisfaction with Buildings and Their Environment As Workplace. Journal of Environmental Psychology 17(1): 69-74.

Gündüz, A.( 1996). Bedensel Engelliler Gözü İle Ülkemizdeki Yaşam Koşulları ve Yerleşim Sorunları: Diğerlerinin Konut Sorunları. Komut, M.E. (ed.), TMMOB, Ankara ,15-16.

Güngör, H. İ. (2005). Temel Tasar. Patates Baskı, İstanbul.

İnce, S. F., Dinç, P. (2008). Akademik Ofislerde Bir Memnuniyet Çalışması. Erciyes Üniversitesi Fen Bilimleri Enstitüsü Dergisi 24: 346 - 363.

Kahvecioğlu, H.L. (1998). Mimarlıkta imaj: mekansal imajın oluşumu ve yapısı üzerine bir model. İ.T.Ü Doktora Tezi, İstanbul.

Karaer, H. (2016). http://www.zirveosgb.com.tr/makaleler/drhalil-karaer/231-ofis-hastaliklari.html. (Erişim Tarihi: 24.11.2016)

Koffka, K. (1935). Reprinted 1999. Principles Of Gestalt Psychology .Routledge, Oxford.

Minez, B. (2013). Mimarlık Eğitimi Sürecinde Bireyin Algı Değişiminin Görsel Çevre Değerlendirme Teknikleri ile İncelenmesi. Trakya Üniversitesi Fen Bilimleri Enstitiüsü, Doktora Tezi, 8.

Mutluer, S.Y. (1997). Tekerlekli Sandalye Kullanan Bedensel Özürlüler İçin Uygun Konut Tasarımı ve Çevre Düzenle- 
mesi. Selçuk Üniversitesi Fen Bilimleri Enstitüsü,Yüksek Lisans Tezi, Konya, 15-16.

Myerson, J., Ross, P. (2003). The 21.st Century Office. Rizzoli, New York.

Soyak, G. (2009). Yeni Çalışma Yöntemlerinin Ofis Binaları İç Mekan Tasarımına Etkileri. Haliç Üniversitesi Fen Bilimleri Enstitüsü, Yüksek Lisans Tezi, İstanbul.

Sundstrom,E., Town, P., Rice, R.V., Osborn, D.P. (1994). Office Noise, Satisfaction, and Performance.Environment and Behavior 26(2): 195.

TDK (2016). Algı.

http://www.tdk.gov.tr/index.php?option=com_gts\&arama= gts\&guid=TDK.GTS.5a9d5c01502328.43788939 (Erişim Tarihi: 10.11.2016)

TS EN ISO 9004 (2001). Kalite Yönetim Sistemleri. Performans İyileştirmeleri için Kılavuz.

TS EN 12464- 1 (2013). Işık ve Aydınlatma- Çalışma Yerlerinin Aydınlatılması için Kılavuz.
Ulucan, H.F., Zeyrek, S. (2012). Ofislerde İş Sağlığı ve Güvenliği. İş Sağlığı ve Enstitüsü Müdürlüğü, Ankara.

UN (1975). Birleşmiş Milletler Özürlü Hakları Bildirgesi . http://www.ohchr.org/EN/Professionallnterest/Pages/Right sOfDisabledPersons.aspx (Erişim Tarihi: 10.11.2016)

Vischer, J.C. (1989). Enviromental Quality in Office. Van Nostrand Reinhold, USA.

Vischer, J.C.(1996). Work Space Strategies: Enviroment as a Tool For Work. Chapmen and Halls, USA.

WHO (2007). Housing, Energy and Thermal Comfort. WHO Regional Office, Denmark.

Yucedag, C., Kaya, L.G., Cetin, M. (2018). Identifying and Assessing Environmental Awareness of Hotel and Restaurant Employees' Attitudes in the Amasra Disitrict of Bartın. Enviromental Monitoring and Assessment 190(2): 60. doi: 10.1007/s10661-017-6456-7. 